\title{
Research on the mode of international tourism cooperation under the background of "the Belt and Road"
}

\author{
Deng Xiaohui ${ }^{1, a}$ \\ ${ }^{1}$ Department of economy management ,Guang'an vocational and technical College,Guang'an \\ 638000, China. \\ adxh815@163.com
}

Keywords: the Belt and Road, tourism, cooperation, mode

\begin{abstract}
The paper analyzed the present situation of tourism cooperation between countries along the area of "the Belt and Road", proposed to build a new tourism cooperation mode between different countries. By forming the tourism league, We can build the international cultural tourism industry, international barrier-free tourism zone, international tourism special economic zone and international tourism city between these countries, so that we can explore new policies and new cooperation mode of international tourism between countries along the area of "the Belt and Road".
\end{abstract}

\section{Introduction}

"The Belt and Road" is "the Silk Road Economic Belt and the 21st-Century Maritime Silk Road" for short. It is a platform for China and relevant countries of the regional cooperation, which can work together to build a community of interests, fate and responsibility in political mutual trust, economic integration and cultural inclusion, destiny and responsibility. Tourism along "The Belt and Road" is across the different country borders and continents, where has the different ecological environment, beautiful natural resources and abundant human resources. It has aroused the concern and attention of the governments, academia and tourism industry. ${ }^{[1]}$

\section{The background analysis of regional tourism cooperation along "The Belt and Road"}

“The Belt and Road Initiative” across Asia and Europe on three continents, includes Asia Pacific and Western Europe two big economic circle and east Asia, central Asia, north Africa and Europe and Asia, three big economic zones."The Belt and Road Initiative"region is divided into eastern, middle and western part.China is at the beginning of eastern part.It's rich in tourism resources in the asia-pacific economic circle, has a long history, the rapid economic development.The middle area is the core. It is the link and channel features cooperation. The region has two river culture and the ancient Egyptian civilization, etc., but relatively scattered tourism resources, which is an important tourism development zone.Western part owns developed economy, abundant tourism resources, especially in the Roman and Greek culture.These resources has laid a solid foundation to the area along the international tourism cooperation. However, spatial distribution of resources, nations, language, religion, government, law, etc., all of these bring challenges for tourism cooperation.As early as in 1998, the United Nations educational, scientific and cultural organization started the "dialogue: silk road integrity research" project, put forward the idea of the silk road to apply for world cultural heritage.Because of the silk road connecting multiple different civilization, nation and state, so in the first support, China is going to joint properties with the five central Asian countries.In 2001, the establishment of the Shanghai economic cooperation organization, provided a good platform to strengthen cooperation.In 2005,Asia-Europe Economic Forum was held in xi 'an,where is the silk road starting point, and further put forward the silk road tourism cooperation, and reached a consensus in xi 'an,which became the blueprint and the direction of the tourism cooperation in other countries. ${ }^{[2]}$ In 2007, the national tourism administration created the silk road tourism planning. In 2013, the 13 countries in Asia and Europe published "The declaration of co-construction and silk road economic belt in xi 'an" , in which mentioned to strengthen tourism cooperation from all over the 
world.In 2014, the National Tourism Administration drafted the "strategic planning of tourism development along the way", planning from the sharing of resources, the wisdom of tourism, tourism brand, platform construction, interconnection and other aspects of integration and cooperation.In 2015, the national development and Reform Commission jointly issued with the ministries of the "push" vision and action to build Belt and Road Initiative, for tourism cooperation, pointed out the direction.

\section{The Belt and Road international tourism cooperation development mode}

Because of The Belt and Road countries in tourism resources and tourism development status shows:In East,West and south part is high, in the middle and north part is low.They occupy the main features and present situation of the leading and showing,just as developed countries in Western Europe and the emerging economies such as China and India as the representative of the country.In The Belt and Road national common response and call, we must have "equality and mutual benefit, solidarity and mutual trust, tolerance and mutual learning, cooperation and win-win" spirit of innovation, actively participate in international cooperation in tourism development model, and build a new mode of travel to The Belt and Road.It includes: creating The Belt and Road Initiative International Tourism Alliance, The Belt and Road International Cultural Tourism Zone, The Belt and Road International Ecological Tourism Zone, tourism service The Belt and Road SAR, The Belt and Road tourism barrier free zone and The Belt and Road international tourism hub city. At the same time,by constructing a channel of tourist traffic network system, we can take many measures, such as increasing the opening of the national tourism market, joint planning and design of tourist routes, creating a unique tourism products and expanding brand influence, and so on. We should continue to deepen the institutional mechanisms and improve the development of planning, to reach the point, line, surface, film, with a comprehensive upgrade.The Belt and Road countries should establish mutual benefit The Belt and Road International Tourism Alliance, make tourism become the national leading industry cooperation. In this way, The Belt and Road National Tourism Alliance has become the integration of tourism resources, East Africa and Europe cultural exchange, leading the international tourism development to a new space vector and an important strategic channel. ${ }^{[3]}$

(a)improve the National Tourism along the way with the top-level design, build along the way of International Tourism Alliance

The Belt and Road countries by the World Tourism Organization (WTO), the World Association of travel agencies (UFTAA) and other international authoritative organization led by tourism, in Belt and Road Initiative governments,the Department of tourism, tourism enterprises, industry organizations to participate in the concerted efforts, set up special tourism cooperation management organization,The Belt and Road international tourism alliance.They are responsible for negotiations, formulate a unified policy and service standards, coordinate the barriers of international tourism cooperation, promote the The Belt and Road national and inter enterprise market opening, line development and cultural exchange, supervision and guidance of the national tourism cooperation project development, guarantee the smooth progress of the project.

\section{(b) Integrate The Belt and Road national natural and cultural tourism resources}

The Belt and Road countries through the tourism industry consolidation excavation, integrated design, development and construction, according to The Belt and Road natural and cultural tourism resources,design tourist routes, products and images.These countries can be regular and irregular organization held a variety of Tourism Festival and host the corresponding all kinds of Tourism Seminar, forum, investment, create a common image, unified packaging, marketing, promotion a belongs to own famous brands. At the same time, they can strengthen the The Belt and Road countries in tourism development, ecological restoration, environmental protection, civilization construction, cultural exchange, cultural heritage, art appreciation, religious customs, identification, aesthetic design on tourism behavior, psychological and other exchanges and cooperation. 


\section{(c)Promote the The Belt and Road tourism integration, and construct The Belt and Road international barrier free Tourism Zone}

The Belt and Road countries through the implementation of "the integration of tourism planning, tourism policy, tourism investment, tourism resources development, tourism resource allocation, tour route design and the wisdom of tourism information, tourism transportation system and tourist market, tourism marketing, tourism and customs clearing mode, tourism service standards, tourism security and Tourism market supervision and other measures ,break the boundaries of sideline, cooperative development, so as to realize the The Belt and Road national tourism.

(d) establishe tourist zones in The Belt and Road important tourist hub city

According to consumer psychology, tourists from all over the world in discrepancy will inevitably buy some tourist commodities; at the same time, the international tourism group or international tourism enterprises in the national commodity circulation must be to develop some special tax policy and customs management system, thus contributing to the in merchandise licensing or quotas to to take care of or priority. In the development and construction of tourism investment and financing, all countries should give support and trust to the enterprise's credit, and give fair treatment in the project competitive negotiation.In the special foreign exchange system, all countries should give a certain special foreign exchange system, and make sure the feasible and convenient visa system to ensure the safety and promote the communication between the tourist and the tourist. In addition, in terms of currency use, the maximum free circulation and convertibility of currencies and foreign exchange should be achieved. In order to expand the foreign tourists in the tourist zone, all countries in the air port should give a certain time visa free.

(e)Use Belt and Road Initiative countries friendly city, create The Belt and Road international tourism city system

The Belt and Road countries based on friendly city, creat The Belt and Road international tourism city system and network which is across Africa and Europe, to enhance international tourism cooperation between bilateral, changing government, industry, enterprises and organizations. Countries can increase organization coordination mechanism among countries in foreign affairs, tourism, customs, culture, simplify international tourists visa clearance procedures, time and procedures between the entry and exit, and increase recognition visa procedures, visa and Visa Electron and other international airport city of international tourists. We can speed up the negotiation, planning and construction of a connection with Asia, Africa, Europe, the three largest plate of international tourism high-speed rail. To increase the The Belt and Road national tourist route number, density and quality, we improve the accessibility and convenience, what can reduce the The Belt and Road international tourism city traffic between time and obstacles.

\section{Summary}

The Belt and Road countries are widely distributed with large space.These countries have all kinds of strange creatures landscape, climate phenomena, national religious culture, modern artificial facilities natural tourism resources and cultural tourism resources, and mainly distribute in the cities along the coast, along the traffic line distribution.Moreover, Europe and Asia are the world's major developed regions and emerging economic development zone.At the background of The Belt and Road, how to establish a long-term mechanism of international tourism cooperation, explore the best development mode, so as to realize the international tourism market, improve the implementation of common The Belt and Road national tourism, it worth arousing our attention.

\section{Acknowledgement}

The paper is the 2016 annual Guang'an social science research planning project:The Belt and Road"under the background of Guang'an tourism cooperation development path and countermeasure research "stage results,issue No.: KT-2016-1 1 ; 2016 - 2017 Guang'an Vocational and Technical 
College project:Sichuan and The Belt and Road along national and regional tourism cooperation" stage results, issue No.: KT-2016-14.

Biography: Deng Xiaohui (1980 -), male, Guang'an Sichuan , Han nationality, master's degree, the major is tourism management, tourism planning.

\section{References}

[1] GUO Peng, DONG Suocheng, LI Zehong, LI Yu, CHENG Hao, YUAN Liang.Research on Spatial Distribution and International Cooperation Model of Tourism Industry in Silk Road[J].Resources Science.2014,36(12):2459-2467.

[2] LI Qiaoling,WANG Xuejun.A Study of Gansu-China Silk Road Tourism Image Design and Promoting Strategy in World Culture Legacy Declaration[J].Journal of Lanzhou University(Social Sciences).2010,38(6):112-118.

[3] DUAN Bojun.The impact of Asian investment bank on promoting China's economic development:a case study of Heilongjiang province and Qigihar City[J].Northern Economy and Trade.2015(6):19-21 